\title{
Challenges and Coping Strategies of Adult Learners in Tertiary Institutions: A Case Study of University of Cape Coast in Ghana
}

\author{
Racheal Ofori \\ Techiman Campus, Valley View University, Ghana \\ Tel:233-247-139-434 E mail: blessedorah@yahoo.com \\ Enoch Danso Okyere (Corresponding Author) \\ Department of Education, Islamic University College, Ghana \\ Tel: 233-244-147-842Ｅ-mail: okyeredanso@yahoo.co.uk
}

Gifty Seiwaa Nyarko

Eulogio Amang Rodriguez Institute of Science and Technology, Philippines

Tel: 233-277-500-800 E-mail: ngifty73@yahoo.com

Received: August 15, 2015 Accepted: Oct 16, 2015 Published: November 1, 2015

doi:10.5296/jse.v5i4.8161 URL: http://dx.doi.org/10.5296/jse.v5i4.8161

\begin{abstract}
The study examined challenges adult learners in the University of Cape Coast face and the strategies they adopt in coping with these challenges. The case study research design was used and involved 18 respondents who were selected through purposive sampling technique. The hermeneutic method was used to analyze the data. The findings show that ICT and library are indispensable learning resources but adult learners have difficulty with their usage. Adult learners fail to avail themselves of counseling services on campus. It is recommended that ICT education should be intensified for these learners. Adult learners should be separated from the younger ones during ICT lessons in order to serve their special needs in the use of this resource. The wireless internet service should be active all the time and should be expanded to serve all halls and nearby hostels of the university.
\end{abstract}


Keywords: Adult Learner, Coping, ICT (Information Communication Technology), Challenges, Counseling. 


\section{Introduction}

Adult learning is relatively a new area of study. Its emergence is dated around the $20^{\text {th }}$ century. This field of study was pioneered by Malcom Knowles in the 1970s (Norman, 1999). It is a field that has little linkage with childhood and adolescence learning. New trends have emerged from the study of adult learning. Tuinjman (1995) explained that they include cross cultural dimensions, adult engagement in practical theorizing, and the ways in which adults learn: distance education, computer assisted instructions open learning system. Adult learners pursue courses in tertiary institutions due to various reasons: compensation for shortcoming in the formal setting, personal, social needs fulfillment and many others. Adult learners possess some characteristics which are: self-directedness and autonomous; experiences and knowledge; goal oriented; relevance oriented; practical; and to be shown respect (Brookfield, 1986). By these characteristics, they are able to pursue any form of education they may find fit to their needs.

Adult learners come together purposely to explore common knowledge and skills and share common experiences. Each adult brings into the learning environment some acquired experiences, knowledge and skills which have influence on how new skills, ideas and experiences are acquired, received and interpreted. Concentrating on the teaching-learning business, the adult learners in the formal setting are of much concern. According to Zumakpeh (2006) "adult education is fast becoming a multi-faceted and multi-sectorial discipline, whose specialty seems to be in the tackling, and solving of problems which other disciplines have created, failed to solve or even failed to comprehend. Though extremely heterogeneous, it does succeed in creating for itself an area of accessibility, cost effectiveness, functionality, relevance, respectability and self-esteem, which it then transmits to its clientele" (p.38).

When adults learn in one another's company, they find themselves engaging in a challenging passionate and creative activity. The acts of teaching and learning- and the creation and alteration of our beliefs, values, actions, relationship and social forms that result from this are ways in which we realize our humanity (Brookfield, 1986).

Adults who come together with the purpose of learning enjoy a lot of privileges since they get the opportunity to learn from one another. This makes them rich in experience. Through this it is seen as an Akan adage translates "until you visit one's farm, you preconceive that you have the biggest farm." They share their knowhow and build good relationships. As they engage in free exchange of ideas, values, beliefs, and practices it gives a clear indication that their society is open, democratic, and healthy.

\section{Statement of the Problem}

Adult learning programmes in Ghana look at areas like literacy and numeracy, health including HIV prevention programmes, income-generating skills training, special learning needs programmes for prisoners, migrants, refugees, the disabled and workers in general and Information Communication Technology training.. The major targets of these programmes are women since the illiteracy rate of women in Ghana is relatively high. 
Distance learning and evening studies are open for adults who want to have access to tertiary education in the tertiary institutions (Ministry of Education, Youth and Sports, 2008).

Some studies also look at the principles of teaching the adult learner. This actually serves as a guide to the teacher (Lieb, 1991).

Some have researched into the challenges teachers in distance learning face. In the United States of America Peck and Varney (2009) from Southern Hampshire University for example reports as:

Despite the number of adult learners who attend our institutions, this population tends to feel invisible on traditional colleges and university campuses where almost everything is geared towards the traditional student. Orientation, welcome week, student support services and extracurricular activities are just a few programmes that are intended to help balance and enrich the lives of $18-22$ year old students (p. 32).

What then becomes of the adult learners? Peck and Varney (2009) in this article cites Kasworm (2008) who says "... many traditional institutions do not offer services for the adult learner" (p.34). Aitchison and Alidou (2009) also see as a challenge and constraint to the adult learner, Information, Communication and Technology and electronic media research. It is seen that high cost and poor connectivity inhibit use.Having considered these few challenges, one wonders how to resonate with adult learners in Ghanaian tertiary institutions; yet little research ever have existed that addressed the issue. The researchers were therefore interested to find out if these were also challenges adult learners in tertiary institutions in Ghana face and the strategies they adopt in order to cope with these challenges by using the University of Cape Coast for a study.In order to achieve the above objectives the study sought to answer the following research questions:

2.1 What challenges do adult learners encounter?

2.2 What support services are available to the adult learner?

\section{Literature Review}

\subsection{Challenges and coping strategies of adult learners in Tertiary Institutions}

Life-long learners can look like anybody and everybody, and there is no stereotypical model. While there is no steadfast model, there are similar traits that most adult learners have in common (Donovant, 2009). The adult learner is typically somebody who requires a program that allows them the ability to balance life and educational aspirations due to a secure job or family obligation. In addition, these life-long learners are often individuals that have very limited funds (Pusser\&Breneman, 2007). These two sets of circumstances are sometimes reason enough for many to feel that the idea of going back to school is out of reach. According to the Council for Adult and Experiential Learning (CAEL) (2000), adult learners experience numerous challenges when entering an educational program. Adult learners today have to deal with a lack of sufficient course offerings with their program of study that fits their schedule (Snyder \&Dillow, 2010). Since most programmes are fashioned out to suit the traditional student, adult learners usually must find a way to attend class while working 
around employment schedules (Snyder \&Dillow, 2010).

Another issue that CAEL saw was the overall duration of a program. According to the Department of Education National Center for Education Statistics (2006), the average time it took to complete a four year degree from 1999 to 2003 was about 55 months, assuming students do not transfer from another institution or take any time off. Those that have attended multiple institutions took longer to complete a degree (U.S. Department of Education National Center for Education Statistics, 2006). Furthermore, these statistics are based on the traditional student that is between the ages of 18-23 years old. These do not reflect students returning for a second degree or seeking a nontraditional degree.

These are not the only roadblocks perspective and current adult learns run into in college enrollment. Additional concerns may include a lack of time to pursue education due to work and family obligation, the cost of educational courses, technology confusion among adult learners, and traditional teaching methods not serving the adult student best (Snyder \& Dillow, 2010).

However, Noel-Levitz, an education-focused consultancy, produces an annual survey called the National Adult Student Priorities Report. One part of this study serves to identify the highest priorities of adult students and the extent to which institutions are satisfying adult students' expectations regarding these priorities. While "academic advising" placed second in importance among adult undergraduate students, it also had the third-highest performance gap, which is the measure of the difference between the importance of an item and the level of satisfaction expressed regarding its provision (Noel-Levitz, 2012). In a $\mathrm{PhD}$ dissertation focused on adult students at one four-year institution, Anderson (2011) found that satisfaction with academic advising positively influenced retention. Thus, advising appears to be an area where institutional improvements can generally be made in order to both better serve the priorities of adult students and increase their persistence in the academic environment. Advisors of adult students ought to anticipate that these students will have noticeably different demands on their time when compared to traditional students. While it is not uncommon for many traditional students to have at least part-time jobs, adult students will often have not only full-time employment, but also other high-priority demands on their time. Varney and Peck, in a 2009 National Academic Advising Association Webinar on "Understanding the Needs of Adult Learners", note that advisors ought to be understanding of adult students' need to potentially take terms off for work and family obligations and help adult students navigate successfully through these potential stop periods (Varney \& Peck, 2009).

Marques and Luna (2005) posit that adult students are not generally on campus as frequently as traditional students, and they cannot necessarily be expected to have the same level of awareness regarding the academic resources that are available to them. In order to combat this lack of awareness of campus resources, Glodek, Link, Pearson and Peck(2011), indicate that their institution, a four-year liberal studies arts college, has found that "outreach tactics such as surveys, e-newsletters, open houses and special events" can be helpful (p.15). 


\section{Methodology}

\subsection{Research Design}

The design is case study. It is a research technique where key factors that may affect the outcome of an activity are identified. Yin (1991:23) as cited in Sarantakos (2005) defines case study as "an empirical inquiry that investigates a contemporary phenomenon within its real-life context when the boundaries between phenomenon and the context are not clearly evident in which multiple sources of evidence are used" (p. 211).

Case study as a research design focuses on direct and verifiable life experiences. Also, it is suitable for in-depth analysis pursuance (Sarantakos, 2005).Nisbert and Watt (1984) as cited in Cohen, Manion\& Morrison (2005) categorized the strengths and weaknesses as follows: the results are more easily understood by a wide audience, they are immediately intelligible; they speak for themselves, they are strong on reality and can be undertaken by a single researcher without needing a full research team. As weaknesses, case study cannot allow for inductive generalization since it only relates to unit of analysis. It does not assure validity, reliability and objectivity because it entails element of personal biases and impressions. Every design has its associated problems. Case study was not adapted for its weaknesses but for its strengths and its appropriateness to the research.

\subsection{Population and Sample}

Participants in the study were from the following categories of people from the University of Cape Coast: Counseling coordinators, lecturers, students (Distance learning, Evening classes and Regular students). The total sample was 18. “... the correct sample size depends on the purpose of the study and the nature of the population under scrutiny" (Cohen, Manion and Morrison, 2005 p. 93). The sample comprisesfour adult learners from the Distance learning group (males \& females), Four adult learners from the Evening classes group (males \& females) and Four adult learners from the regular school group (males \& females) from the University of Cape Coast formed the students' sample. Three lecturers, from the University ofCape Coast and two counseling coordinators, and an academic counselor from the University of Cape Coast were also selected. The respondents were purposively selected because of their importance to adult learning. Purposive sampling, according to Kane (1995), does not involve randomly selected samples in that participants are deliberately chosen because of some qualities that interest the researcher. The justification for these subjects is their significance to the study. Cohen et al (2005) have argued that in purposive sampling, researchers handpick the cases to be included in the sample on the basis of their judgment of their typicality. In this way, the researcher builds up a sample that is satisfactory to his specific needs. As the name suggests the sample has been chosen for a specific purpose. The researchers chose this sample size in order to do critical and in-depth analysis of issues that emanated from the study.

An introductory letter was sent to U.C.C. Counseling centre in order to find counseling coordinators to seek their views on the study. Two coordinators (a male and a female) were interviewed. Since a third person was difficult to find, an academic counselor was added. 
This was because the counselors confirmed that they coordinate with the academic counselors in aspects of the counseling process. In the case of the lecturers, they willingly accepted to partake in the research. They were purposively selected.

Four Regular students were purposively selected from a hostel near the campus. Two of them were males and the other two, females. They were Evening classes and Distance students. A student from each of these two groups was purposively selected and they recommended others who also willingly participated in the research. Each group was made up of two males, two females. They were undergraduate students.

\subsection{Data Collection Procedure}

Purposive sampling technique was used to select the adult learners. A personal introduction was made to each of the respondents after which the study was introduced. An appointment was booked with the respondents two weeks before the interview was conducted. Three different sets of semi-structured interview guides were made for each of the groups (lecturers, counseling coordinators, and adult learners). The interview guide was structured into three parts. The first part was on the challenges adult learners face in the University of Cape Coast, The second part covered the support services the university renders to adult learners and the last part captured how adult learners cope with the challenges of the university environment. Subsidiary questions were asked under each part to elicit the appropriate responses for the study. The duration for the interview was between 15 and 30 minutes.Information was elicited from some respondents through focus group discussion but others were interviewed individually. Apart from the counseling coordinators who were met during the day, the rest of the respondents were met in the evening. The data collection took about five weeks. The responses were recorded and transcribed.

\subsection{Data Analysis}

The hermeneutic method was used to analyze the results from the interview. The hermeneutic is the study of interpretation theory and can either be the art of interpretation or theory and practice of interpretation. The researchers used an audio tape recorder and also kept notes during the interview in order to make sure that all important information was captured. As Patton (2002) succinctly recommends; "the use of a tape recorder does not eliminate the need for taking notes, but does allow you to concentrate on taking strategic and focused notes, rather than attempting verbatim notes" (p.383). The various responses from the interviewees were transcribed from the audio tape recorder onto paper. The results were interpreted based on the research questions. Themes were developed from the research questions and they formed the sub- headings of the analysis. Finally, the validity and reliability of the interpretation of the data were ascertained by thorough checking through playback of the recorder and forwarding the transcript to the respondents for validation. The respondents responded in the affirmative confirming the validity and reliability of the information received from them. 


\section{Results and Discussion}

\subsection{Challenges Adult Learners encounter in the higher education environment}

When the perspectives of adult learners were sought on the challenges they encounter by learning in a higher education environment, one of the student respondents had a complaint and she registered it as problem with the new lecture halls. To her, since the old lecture halls have fixed furniture, they don't struggle for seats but with the new lecture halls, the seats are removable so students move them from one point or area to another for discussions and they usually don't return them. This gives the chance for seat struggling when the seats left in the halls are few. She admitted that the rooms are spacious. Talking about the library, a regular female student made this complain: but the libraries, most of the time, we have to roam the whole library looking for a book and you'll never find one so that one is a problem. Another evening lady student added: there was a time we combed the whole place, the librarian helped us but I couldn't get the information. I was fed up and I slept. I slept there for a while. Some of the books are not helping.

This brings some questions to mind. Are the books not adequate or they are archaic? Are the students lacking the knowledge of how to search and find books at the library or the books are not there? Is it that the lecturers don't find out before they give those books as reference materials or students steal them? It was also noticed that some students don't visit the library at all. Some said it was as a result of their time schedule. They were too busy to go there. Some of the distance education students also said that since they attended lectures over the weekends and worked during the weekdays, they didn't access the library at all. Even during their break times they used it for discussion and at times too, the library would be closed when they were ready to go there.

Adult learners in spite of the fact that ICT has become an indispensable tool in learning had problem with it. A male lecturer commented that these adult learners had problem with using ICT to look for information. He said that some of them had problems with basic computing skills and browsing. This is because they were born before the advent of this form of technology as compared to the young ones who are growing with it. So when he directed them to the internet to look for information, they asked how they should do it. He then said only few in the group are able to access the net for information. He also complained about the frequent breakdown of the wireless on campus and also the small nature of the bandwidth and the narrow nature of the coverage. He would have wished it is extended to the halls and nearby hostels so learners could access it in the comfort of their hostels and halls of residence. A female regular student complained: The ICT, talking about the school internet, most of the time, you go and the network is not working.

ICT is a useful aid to learning however these later comments show how this is also a threat to the studies of adult learners because they have problem with its usage. They usually thanked their stars when they were asked to present the hard copy of their work. Since the library and other reference books and materials are available, they ignore the use of ICT. However those who know how to use it see it as a friendly environment. 
Counseling service is also an aspect of the learning environment. All the respondents admitted the fact that there is a counseling centre on the campus that renders counseling services. It was realized that most of the student don't visit this centre to enjoy the available services. I've never been there for counseling". A female regular student indicated. "I've never been to the counseling centre before." A male regular student added, "I've never been to that place." Another male regular student reiterated. The evening school students never went to the counseling centre because they complained their schedule was too tight. The distance education student also had a similar complain and added that the counseling centre does not hold sessions over the weekends when they come for lectures and that contributed to their inability to go there. They don't also go to their academic counselors for help. It was also gathered that most of them don't know their academic counselors. These students enjoy sharing their own problem with friends than going to the counselor. None of them ever saw a programme organized purposely for adult learners on campus. The entire counseling programmes were for the general student body. Some of these student respondents expected counselors to make themselves known or available to them. They think they cannot share their problems with people they do not know. Others also had the view that counselee should rather go to the counselor and not the vice versa. To some of them, the counselors should create a platform to solicit ideas about problems students encounter so they can help in solving those problem through organized programmes. The lecturers and academic counselor talked of the fact that when they counsel students and realize the problem is above them, they refer these students to the counseling centre for proper or professional counseling. An academic counselor indicated: Now, we are asked to refer them to the counseling unit. That is the policy. It is the university policy that if you have a problem above you as it should, we should refer them, the counselee, eh, to the counseling unit...

A female counselor was asked whether the counseling centre had special slots for adult learners and she answered by saying that their programmes were for the young ones because, they do the same courses, pay the same school fees, pay for the same room so I think it has never been realized that they need anything special. If there has been the need to cater for the young ones who also pay and use services as the adult then there arises the need to cater for the adults too in counseling activities. (A female counselor)

Adult learners are to make inquiries about services available to them. An inquiry was made to find out if these learners do go for available counseling service. The female counselor admitted that the learners know about this service because she said: when they come to first year, there's orientation, they are taught places, the hospital, but you see nothing really happens for people to look for counseling unless there is serious crisis. She complained that even those who come there use the place as their last resort. To her, during orientation, the health Director goes to give a talk once as well as the counseling Director but they are able to find their ways to the hospital but to the counseling centre, no because of their misconceptions. They don't take counseling seriously so they think counseling is for people who have problems- someone who is mad. They have a lot of misconceptions about it because they do not access it. So if someone comes here and friends ask them where are you coming 
from? He will say, I went to visit someone but if it is the hospital he will say I went to the hospital. (a female counselor)

By this she means Africans have put a mask on counseling as good for people who are being chased by something other than that, there is no need for it. Since those who go for the service are unable to tell their colleagues and share the beauties of the service, those who have similar problems are unable to go for the needed help. Though counselors keep creating awareness on radio and at lecture halls, adult learners don't seek for it. This might be as a result of programmes they advertise like "Young and wise" The adult learner might not see its importance to him or her so at the end may decide to neglect it or better, advise a younger person to rather go for the service. It also came to the lime light that females patronize the service more than males. This is because, they like sharing problems. None of the male respondents ever visited the counseling centre but a female said she had been there for some time and this confirms what came out of the findings. The counseling service would be a productive beneficial environment to the adult learners in their learning if they start to patronize the service and also if the centre realizes the need to organize programmes that would be of importance to these adult learners.

\subsection{Support services available to adult learners}

When respondents' thoughts were sought on the support services available to them, a female lecturer had this to say, my courses are practical oriented so we do some kind of role play, field trips with some of the courses. It depends on the particular courses I am teaching. Some of them are classroom oriented, others are field trip based. (a female lecturer)

Another male lecturer asserted: you know, what I do is that I do a lot of things so that I can know their strength. Some of them are seminar based projects, quizzes, discussions and based on this everybody can come out with their strength ..... not that we do quiz one and assignment and then done with it, yeah.

With this it can be seen that adult learners are given needed support in their studies and even they are given flexible assessment so as to unearth their needs and strength for other available support. Some of the lecturers said, they use teaching/learning materials (TLMs) in teaching, while others said because they are lecturers they only lecture. In all, the use of the TLMs is based on the particular course or topic. A male lecturer confirmed: Power point presentation and then depending on the topic, you can use models for example if you are teaching HIV/AIDS, we can use models, we use the vagina models and then we use some form of materials, condoms....(a male lecturer )

Some of the students respondents also said, some lecturers use TLMs while others do not. Some also teach at a reasonable pace to help them understand what is being taught. Another male lecturer gave a counter experience,...we look at them and realize some are a bit older and when you are teaching them in an integrated manner, I mean this normal student thing we have both adult and young ones so we use the same method in teaching and the same assessment because of the time schedule we go, we cannot take every student into consideration especially with large class size (a male lecturer). 
This means that adult learners in such classes are not given the needed support and the needs of the very slow learners are neglected. What then becomes of the adults? Enough avenues are created in this institution to encourage adult learners to be self-directed. The various libraries are there, reading rooms are provided in the various halls of residence, the computer labs are available at both the old site and new site (science), with internet service though not all over the campus. To those who can afford, the private internet cafes are there for use and lecturers can be contacted when one feels the need of them if only they are around. There are a lot of social groups and ethnic groups and even the mother Student Representative Council (SRC) where the students can join to satisfy their academic and social needs. Most of the student respondents talked about finance as a major challenge. Some of the students gave some assertions:...for me, my challenge is let's say finance because as a student and then not on study- leave, I think surviving on campus is very difficult so that has been my challenge, because as I am now, I have many responsibilities, I'm taking care of my home, I have other responsibilities at church, the community too, people look up to you because you are working (a male student)

A female evening student said, "The only problem I face is the paying of my fees." "... financial and other emotional problems”, a male distance student added. An inquiry was made to find out what financial support is available for students. A male counselor had this to say: we assist them. For example, there are some we write to the Dean of students. We work in collaboration with the Dean of students and help them to, if they cannot pay their fees. So the Dean can also appeal to the authorities working on their behalf so they can give them some time to pay...we link with their District Assembly, we write letters on their behalf to the District Assemblies, to their DCEs their MP, for financial assistance (a male counselor)

The school also has some scholarship scheme available to brilliant but needy students. It is also noted that these services are not for only adult learner but also for the traditional university students. It was also known that the young or traditional students usually access this support service more than the adult learners. The result of this may stem from the fact that they are self- reliant or they don't have any information concerning some of these financial avenues or opportunities. Some of the lecturers are able to part with cash to support some of these students. Others also have to give out their reliable books to help their academic work. I remember about three months ago, a woman came, a married woman came here and after interactions, I realized she needed something so I asked her is there something else I can do for you," She smiled and said Yes I have nothing to live on, absolutely nothing .... So I had to part with money and she wasn't the first person anyway? (An academic counselor)

The academic counselor continued: Sometimes too you have to part with reading materials that are so dear to your heart. You don't want to give them out but they don't have money to buy them. I'm talking about those in the age bracket you are talking about so there are many things you have to do apart from the counseling.( an academic counselor) 
Kasworm (2008) said that many traditional institutions do not offer services for the adult learner. The study found out that in the University of Cape Coast, adult learners do enjoy a lot of services. The academic counselor said: I meet such ones on one -on -one basis. I have a schedule for them so sometimes I even have to come here and teach on Saturdays, so that they can catch up with the others who have no problems pertaining to these areas and for that matter, they are able to grasp whatever we teach in class.(an academic counselor) By this, it can be seen that those adult learners who are weak academically are helped by lecturers in order to make up with those who are judged as good. He continued that: "sometimes you have to part cash ..." So those who are bold and are able to share their financial problems, get help when necessary. A counselor also said,... If it is financial,... You realized their MPs and DCEs could be of help and we link them.( a counselor )

The discourse analysis above brings to the fore that a lot of support services are made available to adult learners. In spite of all these support services available to these adult learners, they do encounter some challenges in their studies.

\section{Conclusion}

In conclusion the findings of the study indicate that adult learners who pursue programmes in the University of Cape Coast just like any tertiary institution face challenges such as lack of time to pursue education due to work and family obligation, limited funds, technology confusion and teaching methods not being adapted to suit the needs of adult learners. The tertiary institutions offer support services such as counseling, internet and flexible mode of learning such as distance and evening classes to enable adult learners juggle work with learning.

It is recommended that Counselors should create a platform to solicit ideas about problems old and young students encounter so they can help in solving these problems through organized programmes. Adult learners should be separated from the younger ones during ICT lessons in order to serve their special needs in the use of this resource. The wireless internet service should be active all the time and should be expanded to serve all halls and nearby hostels of the university. Finally, more awareness programmes should be created to advertise the existence of support services available to adult learners. This is because it has the potential of encouraging adult learners to take advantage of these services.

\section{References}

Aitchison, J., \& Alidou, H. (2009). The state and development of adult learning in sub-Saharan Africa: Regional Synthesis Report. Retrieved 17/2/11 from http://www.unesco.org/pvillen/nesico/confintea/confinteacoutries.html

Anderson, K.T. (2011). Linking Adult learner Satisfaction with Retention: The Role of Background Characteristics, Academic Characteristics and Satisfaction upon Retention.Lowa State University.

Brookfield, D.S. (1986). Understanding and facilitating Adult learning: United States of America: Open University Press. 
Cohen, L., Manion, L., \& Morrison, K. (2005).Research Methods in Education. (5 ${ }^{\text {th }}$ ed.). New York: RoutledgeFalmer.

Council for Adult and Experimental Learning (2000, April). Serving adult learners in higher education. Retrieved from http://www.cael.org/alfi/PDF\%20files/Summary\%20of\%20Alfi\%20Principles\%20of\%20Effe ctiveness.pdf

Donovant, B. W. (2009). The New, Modern Practice of Adult Education: Online Instruction in A Continuing Professional Education Setting. Adult Education Quarterly, 59, 227-245 http://dx.doi.org/10.1177/0741713609331546

Glodek.L., Link, R., Pearson, W., \& Peck, C. (2011). What Matters to Adult Learners: Best Practices in Advising. ACHE Annual Conference. 41. http://www.acheinc.org/ache2011/pearsonslides.pdf

Kane, E. (1995). Seeing for yourself research handbook. Washington D. C.: World Bank. http://dx.doi.org/10.1596/0-8213-3453-0

Kasworm, C. (2008). Emotional challenges of adult learners in higher education. In Dirkx, J. (ED). Adult learning and emotional self (p 27-34). New directions in adult and continuing education.(No 120). San Francisco: Jossey Bass. http://dx.doi.org/10.1002/ace.313

Lieb, S. (1991). Principles of adult learning, Phoenix,. AZ: Vision - South Mountain Community. College.

Marques, J., \& Luna, R. (2005). Switching to a Higher Gear: Advising Adult and Traditional Students in Accelerated Learning. The Mentor: An Academic Advising Journal.

Ministry of Education Science and Sports. (2008). The Development and State of Art of Adult Learning and Education (ALE). National Report of Ghana.

Noel-L. (2012). National Adult Student Priorities Report. higher-education/2012-adult-and-online-learner-satisfaction-priorites-reports.

http://www.noellevitz.com/papers-research

Norman, G.R. (1999). The adult learner: A mythical species. Academic Medicine, 74(8). http://dx.doi.org/10.1097/00001888-199908000-00011

Peck, G. L., \& Varney, J. (2009). Clearinghouse Academic Advising Resources. Retrieved 17/2/11 from http:/www.nacada.ksu.edu/clearinghouse/mo2/Adult-learner.html

Pusser, B., \&Breneman, D. (2007).Lumina foundation for education. Returning to learning: Adults' success in college is key to America's future, 1-26.

Sarantakos, S. (2005). Social Research. ( $3^{\text {rd }}$ ed.) New York: Palgrave Macmillan.

Snyder, T. D., \&Dillow, S. A. (2010, April). Digest of education statistics: 2009 (NCES 2010-013). Washington, DC: U.S. Department of Education, National Center for Education Statistics. 


\section{Macrothink}

Journal of Studies in Education

ISSN 2162-6952 2015, Vol. 5, No. 4

U.S. Department of Education, National Center for Education Statistics. (2009). Digest of Education Statistics, 2008 (NCES 2009-020), Chapter 3.

Tuinjman, A. (1995). International Encyclopedia of Education: Adult learning: An overview (Stephen Brookfield) Oxford Pergman press.

Zumakpeh, E.S.K. (2006). The effects of Non- formal Education on the socio-economic development of women in Nadowli District (Ghana). M.phil Thesis (unpublished) University of Ghana, Legon. 